\title{
Kadar Apoprotein A dan Apoprotein B Serum Darah Tikus Putih (Rattus norvegicus L.) Yang Diinduksi Pakan Tinggi Lemak Setelah diberi Ekstrak Etanol Daun Mimba (Azadirachta indica)
}

\author{
Levels Of Apoprotein A And Apoprotein B Blood Serum Of White Rats \\ (Rattus norvegicus L.) Induced High-Fat Ration After Giving \\ Neem Leaf Ethanol Extract (Azadirachta indica)
}

Sri Isdadiyanto*, Siti Muflichatun Mardiati, Agung Janika Sitasiwi

Program Studi Biologi Fakultas Sains dan Matematika Universitas Diponegoro Semarang

*Email: isdadiyanto@yahoo.com

Diterima 29 Januari 2021 / Disetujui 26 April 2021

\begin{abstract}
ABSTRAK
Penelitian ini bertujuan untuk menguji pengaruh ekstrak etanol daun mimba (Azadirachta indica) terhadap kadar apoprotein A dan apoprotein B tikus putih (Rattus norvegicus L.) yang diberi pakan tinggi lemak. Penelitian menggunakan Rancangan Acak Lengkap, sebanyak 24 ekor tikus putih jantan dewasa digunakan sebagai hewan uji, dibagi 6 perlakuan dan 4 kali ulangan. Perlakuan meliputi P0 (control), P1 (pakan tinggi lemak), P2 (simvastatin $8 \mathrm{mg}$ ), P3; P4; dan P5 (uji dosis ekstrak etanol daun mimba 75; 100; dan 125 $\mathrm{mg} / 200 \mathrm{gBB}$ ). Hari terakir perlakuan, hewan dikorbankan dan diambil darahnya untuk analisis kadar apoprotein A dan apoprotein B. Kadar apoprotein A dan apoprotein B serum darah ditentukan dengan metode colorimetric enzymatic menggunakan cobas c reagents kits. Kadar apoprotein A dan apoprotein B serum darah diukur dengan menggunakan Roche/Hitachi cobas c systems automatically calculate. Kesimpulan dari penelitian ini adalah pakan tinggi lemak dapat meningkatkan konsentrasi apoprotein B, ekstrak etanol daun mimba (Azadirachta indica) dapat meningkatkan konsentrasi apoprotein A dan menurunkan konsentrasi apoprotein B.
\end{abstract}

Kata kunci : ekstrak etanol daun Mimba, ransum tinggi lemak, apoprotein A dan apoprotein B

\begin{abstract}
This study aimed to examine the effect of the ethanol extract of neem leaves (Azadirachta indica) on the levels of apoprotein A and apoprotein B of white rats (Rattus norvegicus L.) fed high-fat rations. The study used a completely randomized design, 24 adult male white rats were used as test animals, divided into 6 treatments and 4 replications. The treatments included P0 (control), P1 (high-fat ration), P2 (simvastatin 8 $\mathrm{mg}$ ), P3; P4; and P5 (test dose of ethanol extract of mimba leaves 75; 100, and $125 \mathrm{mg} / 200 \mathrm{gBW}$ ). On the last day of treatment, the animals were sacrificed and their blood was collected for analysis of apoprotein A and apoprotein B levels. The levels of apoprotein A and apoprotein were determined by colorimetric enzymatic method using Cobas $\mathrm{C}$ reagents kits. Blood serum apoprotein $\mathrm{A}$ and apoprotein $\mathrm{B}$ levels were measured using Roche / Hitachi cobas c systems automatically calculate. From this study it can be concluded that high-fat feed can increase the concentration of apoprotein B, ethanol extract of neem leaves (Azadirachta indica) can increase the concentration of apoprotein A and decrease the concentration of apoprotein B.
\end{abstract}

Key words: neem leaf ethanol extract, high-fat ration, apoprotein A and apoprotein B 


\section{PENDAHULUAN}

Hiperlipidemia merupakan kondisi dimana terjadi gangguan metabolisme yaitu kadar kolesterol plasma dan/atau trigliserida mengalami peningkatan. Kadar kolesterol plasma mewakili nilai kolesterol total dan trigliserida mencerminkan kadar kilomikron dan very lowdensity lipoproteins (VLDL) (Katzung, 2002). Kolesterol di dalam darah tidak dalam keadaan bebas bersirkulasi, tetapi dalam partikel-bentuk partikel lipoprotein. Lipoprotein tersusun dari lemak dan protein, di dalam serum darah, lipoprotein dibagi menjadi 4 jenis yaitu kilomikron, VLDL, LDL dan HDL (Mayes and Botham, 2003 ${ }^{\text {a }}$.

Level kolesterol meningkat akibat konsumsi pakan tinggi lemak dapat terjadi karena lemak yang masuk ke dalam tubuh sebagian akan dikonversi menjadi kolesterol. Lemak yang berasal dari sintesis endogen dan ransum, akan ditransportasikan ke hepar. Lemak yang berasal dari sintesis endogen dibebaskan dan ditranportasikan ke hati dalam bentuk asam lemak bebas, sedangkan lemak dari ransum ditranportasikan dalam bentuk kilomikron (Mayes and Botham, 2003 ).

Apolipoprotein (protein dan polipeptida) ditemukan pada setiap lipoprotein. Di dalam tatanama $\mathrm{ABC}$, apolipoprotein utama HDL $(\alpha-$ lipoprotein) dipakai simbol A. Apolipoprotein utama LDL ( $\beta$-lipoprotein) adalah apolipoprotein $\mathrm{B}$, yang juga ditemukan pada VLDL dan kilomikron. Apo B pada kilomikron (B-48) lebih kecil daripada apo B-100 pada LDL atau VLDL. Peran apolipoprotein yaitu: Membentuk bagian struktur dari struktur protein, contohnya apo B, Merupakan kofaktor enzim, contohnya $\mathrm{C}-\mathrm{H}$ dipakai lipoprotein lipase, A-I dipakai lesitin:kolesterol asiltransferase; dan bertindak sebagai ligand untuk interaksi dengan reseptor lipoprotein dalam jaringan, contohnya apo B-100 dipakai oleh reseptor LDL, dan apo A-I dipakai oleh reseptor HDL (Mayes and Botham, 2003 ${ }^{\mathrm{b}}$ ). Haksa (2010) menyatakan bahwa Apoprotein B adalah protein utama di dalam partikel lipoprotein aterogenik dan terutama ada di dalam partikel LDL. Setiap partikel LDL mempunyai satu molekul apo B, hal ini menunjukkan bahwa konsentrasi apoprotein $\mathrm{B}$ berbanding lurus dengan jumlah partikel LDL di dalam tubuh.

Sherwood (2001) menyatakan kalainan pada arteria dapat terjadi karena meningkatnya konsentrasi kolesterol LDL dan VLDL di dalam darah (hiperkolesterol). Meningkatnya konsentrasi kolesterol tersebut dapat terjadi apabila ada gangguan proses sintesis kolesterol di dalam hati atau intestinm tenue. Libby and Theroux (2005) menyebutkan konsentrasi kolesterol LDL yang tinggi dapat menyebabkan terjadinya penimbunan kolesterol di sel endotel, hal ini dapat menyebabkan terjadinya aterosklerosis dan di dinding pembuluh darah terbentuk plak.

Ransum lemak yang masuk ke dalam tubuh dalam jumlah yang banyak dapat menaikan kadar LDL darah dan kadar kolesterol total darah (Setiawati dkk., 2016). Fatimatuzzahro dan Prasetya (2018) menyatakan bahwa tikus putih yang diberi asupan tinggi lemak (3 g/200gBB minyak babi dan $2 \mathrm{~g} / 200 \mathrm{gBB}$ kuning telur bebek) selama 28 hari menyebabkan kenaikan yang tinggi total kolesterol dan TG. Tembe-Fokunang et al. (2019) membuktikan bahwa senyawa dalam daun mimba dapat menurunkan risiko terjadinya penyakit jantung dan pembuluh darah yang disebabkan kadar kolesterol yang tinggi. Ningrum dkk. (2020) menyatakan tidak terdapat perubahan histopatologi pankreas tikus putih yang diberi pakan tinggi lemak dan paparan ekstrak etanol daun mimba. Isdadiyanto et al. (2020) menyatakan bahwa tikus putih yang diberi ransum tinggi lemak dan setelah paparan ekstrak etanol daun mimba selama 48 hari menyebabkan naiknya konsentrasi HDL serta turunnya konsentrasi trigliserid dan LDL.

Hasil analisis ekstrak daun A. indica mengandung 6 senyawa yaitu quercetin 3 o-b-dglucoside, myricetin-3-0-rutinoside, quercetin-3-orutinoside, kaempferol-3-o-rutinoside, Kaempferol-3-o-B-D-glukoside, quercetin-3-o-Lrhamnoside (Chattopadhyay,1999). Lebih lanjut dikatakan bahwa Azadirachta indica pada dosis $500 \mathrm{mg} / \mathrm{kgBB}$ dapat menurunkan kadar kolesterol pada tikus yang diinduksi diabetik (Chattopadhyay and Bandyopadhyay, 2005). Kadar kolesterol dan LDL dapat diturunkan oleh quercetin yang 
terkandung dalam daun mimba (Bentz, 2009). Antioksidan flavonoid yang terkandung dalam daun mimba mampu mencegah superoksida menjadi hidrogen superoksida (Tandi et al., 2016).

Berdasarkan fakta tersebut maka perlu dilakukan penelitian mengenai konsentrasi apoprotein A dan apoprotein B serum darah tikus putih yang diberi pakan tinggi lemak setelah diberi ekstrak etanol daun mimba (A. indica). Penelitian ini bertujuan untuk menguji pengaruh ekstrak etanol daun mimba (A. indica) terhadap kadar apoprotein A dan apoprotein B tikus putih yang diberi pakan tinggi lemak.

\section{METODE PENELITIAN}

Penelitian ini menggunakan tikus putih jantan yang diberi ransum tinggi lemak sebanyak 24 ekor umur 2 bulan, dengan perlakuan pemberian esktrak etanol daun mimba (A. indica) per oral. Penelitian ini menggunakan rancangan acak lengkap dengan 6 perlakuan (selama 48 hari) dan 4 ulangan, yaitu : $\mathrm{P} 0=$ kontrol negatif diberikan ransum komersial, $\mathrm{P} 1=$ kontrol positif diberi ransum lemak tinggi dan kuning telur bebek per oral 2,5 ml / g BB, P2= diberi ransum lemak tinggi dan kuning telur bebek per oral $2,5 \mathrm{ml} / 200$ $\mathrm{g} \mathrm{BB}+8 \mathrm{mg} / \mathrm{g}$ BB simvastatin dalam $1 \mathrm{ml}$ air suling, $\mathrm{P} 3=$ diberi lemak tinggi ransum dan kuning telur bebek secara oral $2,5 \mathrm{ml} / 200 \mathrm{~g} \mathrm{BB}+75 \mathrm{mg}$ / g BW ekstrak etanol daun nimba (A. indica) dalam $1 \mathrm{ml}$ air suling, $\mathrm{P} 4=$ diberi ransum lemak tinggi dan bebek kuning telur per oral 2,5 $\mathrm{ml} / 200$ $\mathrm{g} \mathrm{BB}+100 \mathrm{mg} / \mathrm{g}$ ekstrak etanol daun mimba $(A$. indica) dalam $1 \mathrm{ml}$ air suling, dan P5=diberi ransum lemak tinggi dan telur bebek kuning telur per oral 2,5 ml / $200 \mathrm{~g} \mathrm{BB}+125 \mathrm{mg} / \mathrm{g} \mathrm{BB}$ ekstrak etanol daun mimba (A. indica) dalam $1 \mathrm{ml}$ air suling.

Cara pembuatan ekstrak ethanol daun $A$. indica: Ekstrak daun A. indica yang diperoleh dengan cara memetik daun yang berasal dari satu pohon. Daun yang diperoleh, dicuci bersih dengan air mengalir. Daun dikeringkan dengan oven pada suhu $40{ }^{\circ} \mathrm{C}$ selama 10 hari. Daun yang telah kering, dibuat tepung dengan cara dihancurkan dengan blender, kemudian diayak. Tepung daun dilarutkan diekstraksi dengan menggunakan ethanol murni. Ekstrak ethanol daun A. indica dibuat sediaan bahan perlakuan dengan dosis 75 , $100,125 \mathrm{mg} / 200 \mathrm{gBB} / \mathrm{hari}$.

Cara pembuatan pakan tinggi lemak: Pakan tinggi lemak terdiri dari pakan komersial dan minyak jelantah (reused cooking oil). Minyak jelantah yang digunakan pada penelitian ini diperoleh dari minyak goreng kemasan satu liter yang digunakan untuk menggoreng tahu seberat 450 g selama 10 menit pada suhu $150-165^{\circ} \mathrm{C}$ dengan teknik deep fat frying (Muhartono et al., 2018) sebanyak sembilan kali penggorengan (Hanung et al., 2019).

Konsentrasi apoprotein A dan apoprotein B serum darah dianalisis dengan metode colorimetric enzymatic menggunakan cobas $c$ reagents kits. Konsentrasi apoprotein A dan apoprotein B serum darah ditentukan dengan memakai alat Roche/Hitachi cobas $c$ systems automatically calculate. Konsentrasi apoprotein A dan apoprotein B dianalisis menggunakan ANOVA yang dilanjutkan dengan Uji Duncan dengan taraf signifikansi $5 \%$ dengan menggunakan perangkat lunak SPSS 10,0.

\section{HASIL DAN PEMBAHASAN}

Data hasil pengukuran konsentrasi apoprotein A dan apoprotein B pada tikus Rattus norvegicus L.) setelah perlakuan tersusun pada Tabel 1. Hasil perhitungan rerata konsentrasi apoprotein A pada tiap perlakuan menunjukkan bahwa konsentrasi apoprotein A kelompok tikus putih yang diberi pakan lemak normal dan pakan tinggi lemak, diberi pakan tinggi lemak +75 $\mathrm{mg} / 200 \mathrm{gBB}$ ekstrak etanol daun A. indica, diberi pakan tinggi lemak $+100 \mathrm{mg} / 200 \mathrm{gBB}$ ekstrak etanol daun $A$. indica, diberi pakan tinggi lemak + $125 \mathrm{mg} / 200 \mathrm{gBB}$ ekstrak etanol daun A. indica berbeda signifikan $(\mathrm{P}<0,05) ; \quad$ konsentrasi apoprotein A kelompok tikus putih yang diberi pakan tinggi lemak dan pakan lemak normal, diberi pakan tinggi lemak + $75 \mathrm{mg} / 200 \mathrm{gBB}$ ekstrak etanol daun $A$. indica, diberi pakan tinggi lemak $+100 \mathrm{mg} / 200 \mathrm{gBB}$ ekstrak etanol daun $A$. indica, diberi pakan tinggi lemak +125 $\mathrm{mg} / 200 \mathrm{gBB}$ ekstrak etanol daun $A$. indica berbeda signifikan $(\mathrm{P}<0,05)$; konsentrasi apoprotein $A$ 
kelompok tikus putih yang diberi pakan tinggi lemak + ekstrak etanol daun A. indica dan pakan lemak normal, pakan tinggi lemak berbeda signifikan $(\mathrm{P}<0,05)$; konsentrasi apoprotein $\mathrm{A}$ kelompok tikus putih yang diberi pakan tinggi lemak + ekstrak etanol daun A. indica dan pakan lemak normal, pakan lemak tinggi berbeda signifikan $(\mathrm{P}<0,05)$. Hal ini membuktikan bahwa pakan tinggi lemak dapat menurunkan kadar apoprotein A dan ekstrak etanol daun A. indica dapat meningkatkan konsentrasi apoprotein A tikus putih setelah perlakuan dengan pakan tinggi lemak.
Mayes dan Botham $\left(2003^{\text {b }}\right)$ menyatakan level kolesterol meningkat akibat konsumsi pakan tinggi lemak dapat terjadi karena lemak yang masuk ke dalam tubuh sebagian akan dikonversi menjadi kolesterol. Lemak yang berasal dari sintesis endogen dan ransum, akan ditransportasikan ke hepar. Lemak yang berasal dari sintesis endogen dibebaskan dan ditranportasikan ke hati dalam bentuk asam lemak bebas, sedangkan lemak dari ransum ditranportasikan dalam bentuk kilomikron.

Tabel 1. Data Konsentrasi apoprotein A, apoprotein B dan Kolesterol total (mg/dl) pada tikus semua Kelompok

\begin{tabular}{|c|c|c|c|}
\hline \multirow[b]{2}{*}{$\begin{array}{l}\text { Kelompok } \\
\text { Perlakuan }\end{array}$} & \multicolumn{3}{|c|}{ Variabel } \\
\hline & $\begin{array}{c}\text { Apoprotein A } \\
(\mathrm{mg} / \mathrm{dl}) \\
(\mathrm{Mean} \pm \mathrm{SD})\end{array}$ & $\begin{array}{c}\text { Apoprotein B } \\
(\mathrm{mg} / \mathrm{dl}) \\
(\text { Mean } \pm \mathrm{SD})\end{array}$ & $\begin{array}{c}\text { Kolesterol total } \\
(\mathrm{mg} / \mathrm{dl}) \\
(\mathrm{Mean} \pm \mathrm{SD})\end{array}$ \\
\hline $\mathrm{P} 0$ & $8,25 \pm 0,64^{\mathrm{a}}$ & $3,93 \pm 0,55^{\mathrm{a}}$ & $105,90 \pm 2,37^{a}$ \\
\hline P1 & $2,62 \pm 0,51^{\mathrm{b}}$ & $6,92 \pm 0,46^{\mathrm{b}}$ & $133,51 \pm 2,96^{\mathrm{c}}$ \\
\hline P2 & $6,00 \pm 0,51^{\mathrm{c}}$ & $2,96 \pm 0,20^{\mathrm{c}}$ & $114,49 \pm 2,06^{\mathrm{b}}$ \\
\hline P3 & $6,10 \pm 0,27^{\mathrm{c}}$ & $3,00 \pm 0,16^{\mathrm{c}}$ & $117,07 \pm 0,61^{\mathrm{b}}$ \\
\hline P4 & $6,15 \pm 0,56^{\mathrm{c}}$ & $3,16 \pm 0,32^{\mathrm{c}}$ & $114,80 \pm 1,99^{\mathrm{b}}$ \\
\hline P5 & $6,13 \pm 0,55^{\mathrm{c}}$ & $3,15 \pm 0,29^{\mathrm{c}}$ & $106,18 \pm 2,25^{\mathrm{a}}$ \\
\hline
\end{tabular}

Keterangan: Angka yang diikuti huruf yang sama pada setiap kolom tidak berbeda nyata, huruf yang berbeda menunjukkan perbedaan yang signifikan $(\mathrm{N}=5, \mathrm{P}<0,05)$. $\mathrm{P} 0$ : Kontrol negatif, $\mathrm{P} 1$ : Kontrol positif, diberi pakan tinggi lemak, $\mathrm{P} 2$ : diberi pakan tinggi lemak $+8 \mathrm{mg} / 200 \mathrm{gBB}$ simvastatin, $\mathrm{P} 3$ : diberi pakan tinggi lemak $+75 \mathrm{mg} / 200 \mathrm{gBB}$ ekstrak etanol daun $A$. indica, $\mathrm{P} 4$ : diberi pakan tinggi lemak $+100 \mathrm{mg} / 200 \mathrm{gBB}$ ekstrak etanol daun A. indica, P5: diberi pakan tinggi lemak $+125 \mathrm{mg} / 200 \mathrm{gBB}$ ekstrak etanol daun $A$. indica

Hasil perhitungan rerata konsentrasi apoprotein B pada perlakuan kelompok tikus putih yang diberi pakan tinggi lemak + ekstrak etanol daun A. indica dan pakan lemak normal maupun pakan tinggi lemak memperlihatkan perbedaan yang signifikan $(\mathrm{P}<0,05)$. Hasil ini menunjukkan bahwa konsentrasi apoprotein B kelompok tikus putih yang diberi pakan lemak normal dan pakan tinggi lemak, diberi pakan tinggi lemak +75 mg/200gBB ekstrak etanol daun A. indica, diberi pakan tinggi lemak $+100 \mathrm{mg} / 200 \mathrm{gBB}$ ekstrak etanol daun $A$. indica, diberi pakan tinggi lemak + $125 \mathrm{mg} / 200 \mathrm{gBB}$ ekstrak etanol daun A. indica berbeda signifikan $(\mathrm{P}<0,05)$; konsentrasi apoprotein $\mathrm{B}$ kelompok tikus putih yang diberi pakan tinggi lemak dan pakan lemak normal, diberi pakan tinggi lemak $+75 \mathrm{mg} / 200 \mathrm{gBB}$ ekstrak etanol daun $A$. indica, diberi pakan tinggi lemak $+100 \mathrm{mg} / 200 \mathrm{gBB}$ ekstrak etanol daun $A$. indica, diberi pakan tinggi lemak +125 $\mathrm{mg} / 200 \mathrm{gBB}$ ekstrak etanol daun A. indica berbeda signifikan $(\mathrm{P}<0,05)$; konsentrasi apoprotein $\mathrm{B}$ kelompok tikus putih yang diberi pakan tinggi lemak + ekstrak etanol daun A. indica dan pakan lemak normal, pakan tinggi lemak berbeda signifikan $(\mathrm{P}<0,05)$; konsentrasi apoprotein $\mathrm{B}$ kelompok tikus putih yang diberi pakan tinggi lemak + ekstrak etanol daun A. indica dan pakan lemak normal, pakan lemak tinggi berbeda signifikan $(\mathrm{P}<0,05)$. Hal ini membuktikan bahwa pakan tinggi lemak meningkatkan konsentrasi apoprotein B dan ekstrak etanol daun A. indica 
dapat menurunkan konsentrasi apoprotein B pada tikus putih setelah perlakuan dengan pakan tinggi lemak.

Haksa (2010) menyatakan bahwa Apoprotein B adalah protein utama di dalam partikel lipoprotein aterogenik dan terutama ada di dalam partikel LDL. Setiap partikel LDL mempunyai satu molekul apo $\mathrm{B}$, hal ini menunjukkan bahwa konsentrasi apoprotein B berbanding lurus dengan jumlah partikel LDL di dalam tubuh.

Prevalensi aterosklerosis dapat diakibatkan oleh banyak faktor yang berkaitan dengan pola hidup dan kebiasaan yang cenderung mengonsumsi ransum tinggi lemak (Maryani dkk., 2016). Sherwood (2001) menyatakan kalainan pada arteria dapat terjadi karena meningkatnya konsentrasi kolesterol LDL dan VLDL di dalam darah (hiperkolesterol). Meningkatnya konsentrasi kolesterol tersebut dapat terjadi apabila ada gangguan proses sintesis kolesterol di dalam hati atau intestinm tenue. Libby and Theroux (2005) menyebutkan konsentrasi kolesterol LDL yang tinggi dapat menyebabkan terjadinya penimbunan kolesterol di sel endotel, hal ini dapat menyebabkan terjadinya aterosklerosis dan di dinding pembuluh darah terbentuk plak.

Hasil perhitungan rerata konsentrasi kolesterol total pada perlakuan kelompok tikus putih yang diberi pakan tinggi lemak + ekstrak etanol daun $A$. indica dan pakan lemak normal maupun pakan tinggi lemak memperlihatkan perbedaan yang signifikan $(\mathrm{P}<0,05)$. Hasil ini menunjukkan bahwa konsentrasi kolesterol total kelompok tikus putih yang diberi pakan lemak normal dan pakan tinggi lemak, diberi pakan tinggi lemak $+75 \mathrm{mg} / 200 \mathrm{gBB}$ ekstrak etanol daun $A$. indica, diberi pakan tinggi lemak +100 $\mathrm{mg} / 200 \mathrm{gBB}$ ekstrak etanol daun A. indica, diberi pakan tinggi lemak $+125 \mathrm{mg} / 200 \mathrm{gBB}$ ekstrak etanol daun $A$. indica berbeda signifikan $(\mathrm{P}<0,05)$; konsentrasi kolesterol total kelompok tikus putih yang diberi pakan tinggi lemak dan pakan lemak normal, diberi pakan tinggi lemak +75 $\mathrm{mg} / 200 \mathrm{gBB}$ ekstrak etanol daun A. indica, diberi pakan tinggi lemak $+100 \mathrm{mg} / 200 \mathrm{gBB}$ ekstrak etanol daun $A$. indica, diberi pakan tinggi lemak + $125 \mathrm{mg} / 200 \mathrm{gBB}$ ekstrak etanol daun A. indica berbeda signifikan $(\mathrm{P}<0,05)$; konsentrasi kolesterol total kelompok tikus putih yang diberi pakan tinggi lemak + ekstrak etanol daun A. indica dan pakan lemak normal, pakan tinggi lemak berbeda signifikan $(\mathrm{P}<0,05)$; konsentrasi kolesterol total kelompok tikus putih yang diberi pakan tinggi lemak + ekstrak etanol daun A. indica dan pakan lemak normal, pakan lemak tinggi berbeda signifikan $(\mathrm{P}<0,05)$. Ha ini sesuai dengan hasil penelitian Setiawati dkk. (2016) asupan lemak ke dalam tubuh dengan jumlah yang banyak dapat meningkatkan kolesterol total darah. Hasil rerata konsentrasi kolesterol total berbanding lurus dengan konsentrasi Apoprotein B (Tabel 1).

Aterosklerosis terkait erat dengan peningkatan LDL. Kadar LDL yang tinggi menyebabkan tingginya kadar LDL pada tunika intima, selanjutnya LDL tunika intima mengalami oksidasi dan menarik monosit dari sirkulasi darah, kemudian terbentuk makrofag (Yanuartono, 2007). Terjadinya akumulasi lemak, makrofag serta trombosit pada lapisan intima dan lapisan media menyebabkan dinding pembuluh darah menebal yang mengakibatkan diameter lumen semakin berkurang atau menyempit (Zhou et al., 2016).

Berdasarkan rerata konsentrasi apoprotein A dan apoprotein B pada perlakuan menunjukkan bahwa pakan tinggi lemak berpotensi terjadinya risiko penyakit jantung koroner dan ekstrak etanol daun $A$. indica dapat menurunkan risiko penyakit jantung koroner pada tikus putih setelah perlakuan dengan pakan tinggi lemak. Bentz (2009) menyatakan bahwa kadar kolesterol total dan LDL dapat diturunkan oleh quercetin yang terkandung dalam daun mimba, yaitu dengan jalan sekresi Apo-B 100 akan di hambat. Aktivitas enzim HMG-CoA reduktase juga dihambat oleh Quercetin, enzim HMG-CoA reduktase berperan pada sintesis kolesterol. Quercetin bersifat antioksidan, sehingga oksidasi LDL dapat dicegah yaitu radikal bebas akan diikat dan peroksidasi lipid akan dihambat. Choy et al. (2019) menyatakan bahwa sebagai antioksidan flavonoid mampu mencegah superoksida menjadi hidrogen superoksida. Hal ini dapat menyebabkan produksi ROS menurun,sehingga terjadinya stres oksidatif akan dihambat dan inflamasi dan pelepasan sitokin proinflamasi TNF- $\alpha$ tidak terjadi. 


\section{KESIMPULAN}

Berdasarkan hasil dan pembahasan yang telah dilakukan, maka dapat disimpulkan bahwa pakan tinggi lemak dapat meningkatkan konsentrasi apoprotein B, ekstrak etanol daun mimba (Azadirachta indica) dapat meningkatkan konsentrasi apoprotein A dan menurunkan konsentrasi apoprotein B.

\section{UCAPAN TERIMA KASIH}

Penulis mengucapkan terimakasih kepada Fakultas Sains dan Matematika Universitas yang telah membiayai penelitian ini dengan dana DIPA Fakultas Sains dan Matematika Universitas Diponegoro Nomor: /UN7.5.8/HK/2019 tanggal Maret 2019, sesuai dengan Perjanjian Tugas Pelaksanaan Penelitian Para Dosen Di Jurusan Biologi Fakultas Sains dan Matematika Universitas Diponegoro No. 4885/UN7.5.8/PP/2019 tanggal 1 April 2019.

\section{DAFTAR PUSTAKA}

Bentz, A. B. 2009. A review of quercetin: chemistry, antioxidant properties, and bioavailability. Journal of Young Investigators, 19(10), 120-128.

Chattopadhyay, R.R. 1999. Possible mechanism of antihyperglycemic effect of Azadirachta indica leaf extract. J of Ethnopharmacol. 67: 373-376.

Chattopadhyay R.R., M. Bandyopadhyay. 2005. Effect of azadiractha indica leaf extract on serum lipid profil changes in normal and streptozotocin induced diuretic rats.African J. of Biomedical Research. 8:101-104

Choy, K. W., D. Murugan, X. Leong, R. Abas, A. Alias, M. R. Mustafa. 2019. Flavonoids as Natural Anti- Inflammatory Agents Targeting Nuclear Factor-Kappa B (NFkB) Signaling in Cardiovascular Diseases: A Mini Review. Fronti Pharmacol, 10, 1295. https://doi.org/10.3389/fphar.2019.01295

Fatimatuzzahro, N., R. C. Prasetya. 2018. Efek Seduhan Kopi Robusta terhadap Profil Lipid Darah dan Berat Badan Tikus yang Diinduksi Diet Tinggi Lemak. Jurnal
Kedokteran Brawijaya, 30(1), 7-11. https://doi.org/10.21776/ub.jkb.2018.030.01 .2

Haksa, K. 2010. Kadar kolesterol normal bukan jaminan terbebas dari risiko penyakit jantung koroner. 17 September 2010. Kompas.com. All rights reserved.

Hanung, A., F. Saktini, A.R. Gumay. 2019. Pengaruh Frekuensi Penggorengan Minyak Jelantah Terhadap Diameter dan Gambaran Histopatologi Lumen Aorta Tikus Wistar (Rattus novergicus). Jurnal Kedokteran Diponegoro. 8 (1): 26-37.

Isdadiyanto, S., A. J.Sitasiwi, S. M. Mardiati. 2020. The Lipid Profile of Rats (rattus norvegicus L.) Induced by High Fat Ration after Exposed to Ethanolic Neem (Azadirachta indica) Leaf Extract. J. Phys: Conf. Ser. 1524012126.

Katzung, B.G. 2002. Farmakologi dasar dan klinis. Edisi 8. Vol 2. Penerbit Salemba Medika. Jakarta. 466-470.

Libby, P., P. Theroux. 2005. Pathophysiology of coronary artery disease. Circulation. 111:3481-3488.

Maryani, P. E., Ulfa, E. U., E. Rachmawati. 2016. Pengaruh Ekstrak Metanol Daun Kayu Kuning (Arcangelisia flava (L.) Merr.) terhadap Kadar Kolesterol Total dan Trigliserida Tikus Hiperlipidemia. e-Jurnal Pustaka Kesehatan. 4 (1): 20-26.

Mayes, P.A., K.M. Botham. 2003 . Lipid Storage \& Transport. Harper's Illustrated Biochemistry, $26^{\text {nd }}$ edition. Mc.Graw Hill, 205-217.

Mayes, P.A., K.M. Botham. 2003 ${ }^{\text {b }}$ Cholesterol Synthesis, Transport, and Excretion. Harper's Illustrated Biochemistry, $26^{\text {nd }}$ edition. Mc.Graw Hill, 219-227.

Muhartono., P. A.Yudistira, N. T.Putri, T. N. Sari, Oktafany. 2018. Minyak Jelantah Menyebabkan Kerusakan pada Arteri Koronaria, Miokardium, dan Hepar Tikus Putih (Rattus norvegicus) Jantan Galur Sprague dawley. Jurnal Kedokteran Unila. 2 (2): 129-135. 
Ningrum. E.W.C., S. Isdadiyanto, S. M. Mardiati. 2020. Histopathology of Pancreas in White Rats (Rattus norvegicus L.) that Given with High-Fat Diet and Neem Leaf Ethanol Extract (Azadirachta indica A. Juss). Buletin Anatomi dan Fisiologi. 5(2). 23-28

Setiawati, T., U., Atmomarsono, B. Dwiloka. 2016. Kadar Lemak dan Profil Asam Lemak Jenuh, Asam Lemak Tak Jenuh Daging Ayam Broiler dengan Pemberian Pakan Mengandung Tepung Daun Kayambang (Salvinia molesta). Jurnal Teknologi Hasil Pertanian. 9 (2): 1-8.

Sherwood, L. 2001. Human Phisiology: From Cells to Systems. A Division of Internasional Thomson Publishing Inc. All Right Reserved.

Tembe-Fokunang, E. A., F. Charles, N. Kaba, G. Donatien, A. Michael, N. Bonaventure. 2019. The Potential Pharmacological and Medicinal Properties of Neem (Azadiraachta indica) in the Drug Development of Phytomedicine. Journal of Complementary and Alternative Medical Research. 7 (1): 1-18.

Yanuartono. 2007. Peran Diet Lemak dan/atau Kolesterol Tinggi pada Pembentukan Plak Ateroma Aorta Tikus Putih (Sprague Dawley). Indonesian Journal of Veterinary Science. 25 (1): 1-10.

Zhou, Z., Y. Wang, Y. Jiang, Y. Diao, P. Strappe, P. Prenzler, J. Ayton, C. Blanchard. 2016. Deep-fried Oil Consumption in Rats Impairs Glycerolipid Metabolism, Gut Histology and Microbiota Structure. Lipids in Health and Disease. 15 (86): 1-11. 